\title{
A Study on Consumer Satisfaction towards Reliance Retail Market in Erode City
}

\author{
M. Prema* \\ Assistant Professor, PG Department of Commerce (CA), Vellalar College for Women, \\ Erode, Tamilnadu, India; premadhakshitha@gmail.com
}

\begin{abstract}
Retailing is one of the booming marketing sectors in India which contributes a vital role in terms of economy and work force. Every retailer has their own policies and strategies to acquire more number of consumers with quality and cost effectiveness. This study has been carried out to find out the personal perception and overviews of consumers about Reliance retail market in Erode city. The research is descriptive in nature. The collected data are analyzed by using the statistical tools such as percentage analysis, chi-square analysis and weighted average analysis. This study pointed out that the grocery items are purchased in huge quantity when compared to other products and the major problem faced by the consumers is a long waiting time in billing for their purchased products.
\end{abstract}

Keywords: Chi-Square, Factors, Perception, Retailing, Satisfaction

\section{Introduction}

Retail market in India is one of the vital markets which accounts for about 10 per cent of its Gross Domestic Product (GDP) and presently stands second after agriculture ${ }^{1}$. The retail market plays a vital role in building up the world economic value during economic crisis and downstream. In this modern era, due to drastic change in consumers' lifestyle, urbanization and globalization, the existence of unorganized retail sector has been gradually replaced with organized retail stores. There are various retail markets mushrooming in Indian market. The Reliance retail market is one of the largest retail markets organized by Reliance industries. Its retail outlets offer groceries, home appliances, apparels, foot wears, food products, electronic goods, vegetables and fruits. In this context, the present study intends to analyze the personal perception of consumers towards Reliance retail market in Erode city.

\section{Review of Literature}

Susmit Jain $²$ concluded that organized retailers should make a vigil on needs, desires, and preferences of potential and existing customers in order to acquire and retain them. Rajesh K. Yadav and Manoj Verma ${ }^{3}$ found that the customers' satisfaction is more towards organized retail store than the conventional grocery stores in relation with price and benefits in shopping. Shanthi ${ }^{4}$ pointed out that the variables such as gender, marital status and occupation are the key factors that determine the satisfaction level of consumers towards retail stores. Ankita Jangde and Bhuvanesh Kumar Sharma 5 concluded that product quality is the most important factor and to maintain such quality the retailer has to consider the ways to improve it further.

\section{Objectives of the Study}

- To evolve the shopping pattern of consumers in Reliance retail market.

- To analyze the factors influencing the level of satisfaction of consumers towards Reliance retail market.

- To identify the problems encountered by the consumers while purchasing in Reliance retail market.

\section{Research Methodology}

Convenience Sampling method has been adopted in choosing the sample. The proposed research study was based both on primary and secondary data. The primary data required for the study was collected through a well structured questionnaire. A sample of 150 respondents was selected from Erode city. The collected data have been analyzed by using different statistical tools, such as Simple Percentage Analysis, Chi-Square Analysis and Weighted Average Analysis. The required secondary data was collected from various journals, magazines and related websites. 


\section{Hypothesis of the Study}

$\mathrm{H}_{\mathrm{o}}$ : There is no significant association between the Demographic factors (Age, Gender, Occupation, Marital Status and Monthly Income) and the factors influencing the level of satisfaction (Quality, Price, Variety, Services and offers, Benefits and schemes) of consumers towards Reliance market.

\section{Analysis and Discussion}

\subsection{Shopping Pattern of Consumers in Reliance Retail Market}

The shopping pattern of consumers in Reliance retail market is examined by considering the factors namely Period of visit, Product purchased, Awareness on Reliance brand, Awareness on promotional offer and Preferred scheme of Reliance retail market. The results are presented in Table 1.

Table 1. Shopping Pattern of Consumers in Reliance Retail Market

\begin{tabular}{|c|c|c|}
\hline Variables & $\begin{array}{c}\text { No. of } \\
\text { Respondents }\end{array}$ & $\begin{array}{c}\text { Percentage } \\
(\%)\end{array}$ \\
\hline \multicolumn{3}{|l|}{ Period of Visit } \\
\hline First Time & 6 & 4 \\
\hline Once a Week & 38 & 25 \\
\hline Once a Month & 62 & 41 \\
\hline Weekends & 25 & 17 \\
\hline Occasionally & 19 & 13 \\
\hline Total & 150 & 100 \\
\hline \multicolumn{3}{|l|}{ Product Purchased } \\
\hline Vegetables and Fruits & 15 & 10 \\
\hline Home ware & 31 & 21 \\
\hline Food items, Bakery and Beverages & 25 & 17 \\
\hline Groceries & 74 & 49 \\
\hline Dairy products & 5 & 3 \\
\hline Total & 150 & 100 \\
\hline \multicolumn{3}{|l|}{ Awareness on Reliance Brand } \\
\hline Aware & 113 & 75 \\
\hline Unaware & 37 & 25 \\
\hline Total & 150 & 100 \\
\hline \multicolumn{3}{|l|}{ Awareness on Promotional Offer } \\
\hline Aware & 125 & 83 \\
\hline Unaware & 25 & 17 \\
\hline Total & 150 & 100 \\
\hline \multicolumn{3}{|c|}{ Preferred Scheme of Reliance Retail Market } \\
\hline Membership Card & 39 & 26 \\
\hline Discounting Schemes & 111 & 74 \\
\hline
\end{tabular}

Source: Primary Data
Table 1 reveals that a maximum of $41 \%$ of the respondents are purchasing at Reliance retail market once a month, 49\% of the respondents are purchasing grocery items, $75 \%$ of the respondents are aware of Reliance retail brand, $83 \%$ of the respondents are aware of the promotional offers provided by the Reliance retail market and $74 \%$ of the respondents prefer discounting schemes provided at Reliance retail market.

\subsection{Factors Influencing the Level of Satisfaction towards Reliance Retail Market}

The factors influencing the level of satisfaction of consumers towards Reliance retail market such as Quality, Price, Variety, Services and offers, Benefits and schemes are analyzed. The significant association between Age, Gender, Occupation, Marital Status, Monthly Income and the factors influencing the level of satisfaction of the consumers are analyzed by framing a null hypothesis and the same has been tested with Chi-square test at $5 \%$ level of significance. The results are shown in Table 2.

Table 2. Factors Influencing the Level of Satisfaction

\begin{tabular}{|l|l|l|l|l|}
\hline $\begin{array}{l}\text { Demographic } \\
\text { Variables }\end{array}$ & $\begin{array}{c}\text { Degrees of } \\
\text { Freedom }\end{array}$ & $\begin{array}{c}\text { Calculated } \\
\text { Value }\end{array}$ & $\begin{array}{l}\text { Table } \\
\text { Value }\end{array}$ & Result \\
\hline Age & 6 & 6.55 & 12.60 & $\begin{array}{l}\text { Not } \\
\text { Significant }\end{array}$ \\
\hline Gender & 2 & $39.20^{*}$ & 5.99 & Significant \\
\hline Occupation & 8 & $65.28^{*}$ & 16.00 & Significant \\
\hline Marital Status & 2 & $12.30^{*}$ & 5.99 & Significant \\
\hline Monthly Income & 6 & $15.58^{*}$ & 12.60 & Significant \\
\hline
\end{tabular}

Source: Computed from Primary Data *-Significant at 5\% level

Table 2 reveals that there is a significant association between gender, occupation, marital status, monthly income and the factors influencing the level of satisfaction of consumers. In contrast, age has no significant association with the factors influencing the level of satisfaction of consumers towards the Reliance retail market.

\subsection{Problems Faced While Purchasing in the Reliance Retail Market}

The most important problems faced by the consumers while purchasing in Reliance retail market include Inadequate space inside the store, Non-availability of organic farm products, Limited Branded Products, Relatively costlier and Delay in Billing. These problems are analyzed based on the ranking given by the respondents through Weighted Average Ranking Analysis and the results are shown in Table 3. 
Table 3. Problems Faced by the Respondents

\begin{tabular}{|l|c|c|c|}
\hline Problems & $\begin{array}{l}\text { Total } \\
\text { Score }\end{array}$ & $\begin{array}{l}\text { Weighted } \\
\text { Average }\end{array}$ & Rank \\
\hline Inadequate space inside the store & 395 & 26.33 & 5 \\
\hline $\begin{array}{l}\text { Non-availability of organic farm } \\
\text { products }\end{array}$ & 483 & 32.20 & 2 \\
\hline Limited branded products & 407 & 27.13 & 4 \\
\hline Relatively costlier & 477 & 31.80 & 3 \\
\hline Delay in billing & 488 & 32.53 & 1 \\
\hline
\end{tabular}

Source: Primary Data

Table 3 exhibits that 'Delay in billing' is ranked as the most significant problem with a weighted score of 32.53 followed by 'Non-availability of organic farm products', 'Relatively costlier', 'Limited branded products', 'Inadequate space inside the store' with a weighted score of $32.30,31.80,27.13$ and 26.33 respectively.

\section{Suggestions}

The following suggestions have been made based on the findings of the study

- Most of the respondents prefer to purchase grocery items in the Reliance retail market. Hence, based on the needs of the consumers, organic fresh farm products can be sold in the store.

- The most important problem faced by the respondents in Reliance retail market is delay in billing. The store management can increase the number of billing points with more space to convince the consumers.

\section{Conclusion}

The fast development of towns and cities encompasses urbanization and globalization. In this era, it is essential for the retailer to change the layout of the store to attract the consumers. The Reliance retail market reallocates its stores from time to time based on the consumers' shopping behaviour, needs and level of satisfaction in order to make them experience a delightful shopping. The study revealed that the demographic factors namely, gender, occupation, marital status and monthly income have an influence on the level of satisfaction towards shopping at Reliance retail market. The suggested measures, if undertaken by the store management would satisfy the consumers further.

\section{References}

1. Available from: https://en.wikipedia.org/wiki/Retailing_in_India.

2. Susmit Jain. A Critical Study of Consumer Preferences Towards Organized Retail In Jaipur. International Journal of Research In Commerce and Management. 2011; 2(10):99-115.

3. Rajesh K. Yadav and Manoj Verma. Consumer Preference towards Retail Stores for Food and Grocery in Evolving Retail Market. International Letters of Social Sciences and Humanistic Sciences. 2015; 60:102-11. https://doi.org/10.18052/www.scipress.com/ ILSHS.60.102

4. Shanthi. Retail Marketing - A Study of Customers Preference towards Retail Stores in Coimbatore City. Intercontinental Journal of Marketing Research Review. 2016; 4(3):105-13.

5. Ankita Jangde and Bhuvanesh Kumar Sharma. Understanding Shopper Behaviour and Evaluation of Customer Experience at Selected Stores of Reliance Retail. International Journal of Research. 2018; 7(7):537-48. 